\title{
POTENTIAL HAZARDS FROM FLOODFLOWS IN GRAPEVINE CANYON, DEATH VALLEY NATIONAL MONUMENT, CALIFORNIA AND NEVADA
}

By James C. Bowers

\section{U.S. GEOLOGICAL SURVEY}

Water-Resources Investigations Report 89-4063

Prepared in cooperation with the

NATIONAL PARK SERVICE






\section{DEPARTMENT OF THE INTERIOR}

MANUEL LUJAN, JR., Secretary

\section{U.S. GEOLOGICAL SURVEY}

Dallas L. Peck, Director

For additional information write to:

\section{District Chief}

U.S. Geological Survey

Federal Building, Room W-2234

2800 Cottage Way

Sacramento, CA 95825
Copies of this report can be purchased from:

U.S. Geological Survey

Books and Open-File Reports Section

Federal Center, Bldg. 810

Box 25425

Denver, CO 80225 


\section{CONTENTS}

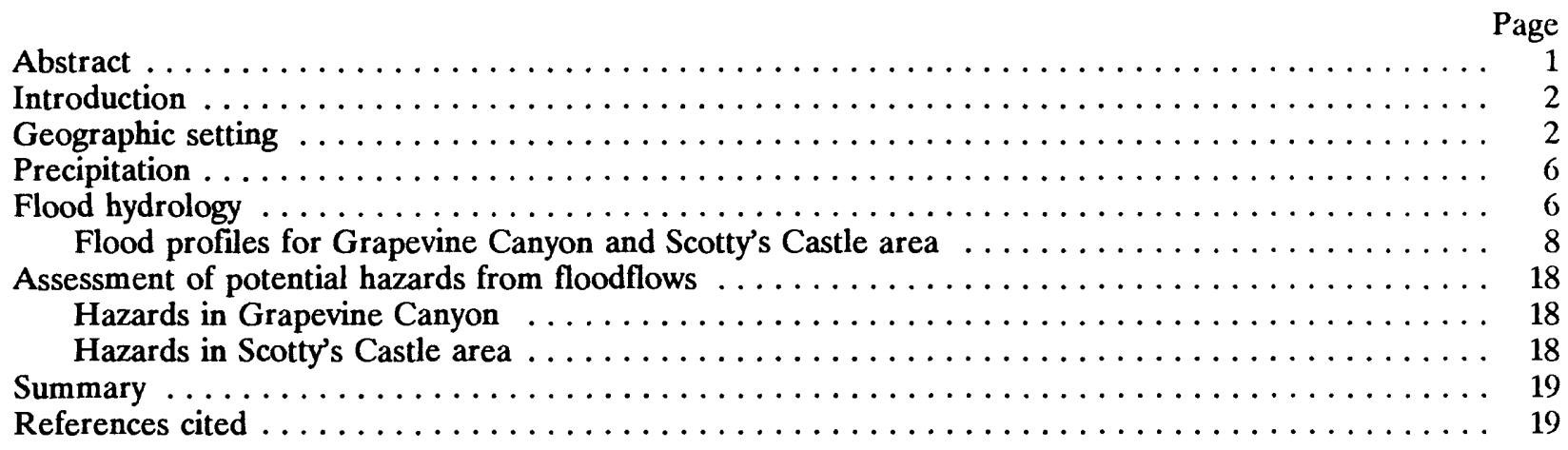

\section{ILLUSTRATIONS}

Plate 1. Flood-inundation map of Grapevine and Tie Canyons near Scotty's Castle, Death Valley National Monument, California ........................ In pocket

Figure 1. Profile of Grapevine Canyon and map showing location of cross sections and data points . . . . 4

2. Cross sections of Grapevine and Tie Canyons showing 25-year, 100-year, and estimated



\section{TABLES}

Page

Table 1. Channel-bed and road elevations in Grapevine Canyon $\ldots \ldots \ldots \ldots \ldots \ldots \ldots \ldots \ldots \ldots$

2. Estimated flood discharges at cross sections in Grapevine and Tie Canyons . . . . . . . . . 7

3. Estimated flood levels at cross sections in Grapevine and Tie Canyons . . . . . . . . . . . 9 


\section{CONVERSION FACTORS}

The inch-pound system of units is used in this report. For readers who prefer metric (International System) units, the conversion factors for the terms used in this report are listed below:

\begin{tabular}{ll|l}
\hline \multicolumn{1}{c|}{ Multiply inch-pound unit } & By & To obtain metric unit \\
\hline cubic foot per second $\left(\mathrm{ft}^{3} / \mathrm{s}\right)$ & 0.02832 & cubic meter per second \\
foot & 0.3048 & meter \\
foot per mile $(\mathrm{ft} / \mathrm{mi})$ & 0.1894 & meter per kilometer \\
inch & 25.4 & millimeter \\
mile & 1.609 & kilometer \\
square mile $\left(\mathrm{mi}^{2}\right)$ & 2.590 & square kilometer \\
\hline
\end{tabular}

\section{DEFINITION OF TERMS}

Recurrence interval: The average time interval between occurrences of a hydrologic event or flood of a given or greater magnitude.

Sea level: In this report "sea level" refers to the National Geodetic Vertical Datum of 1929 (NGVD of 1929)--a geodetic datum derived from a general adjustment of the first-order level nets of both the United States and Canada, formerly called Sea Level Datum of 1929.

Water year: The water year starts October 1 and ends September 30; it is designated by the calendar year in which it ends. 


\title{
POTENTIAL HAZARDS FROM FLOODFLOWS IN GRAPEVINE CANYON, DEATH VALLEY NATIONAL MONUMENT, CALIFORNIA AND NEVADA
}

\author{
By James C. Bowers
}

\begin{abstract}
The Grapevine Canyon drainage basin is located on the steep western slope of the Grapevine Mountains, which form part of the eastern boundary of Death Valley. Grapevine Canyon is steep and winding, and in many places, Grapevine Canyon Road covers the entire width of the canyon floor. Scotty's Castle, a popular visitor attraction in Death Valley National Monument, is located along the road about one-third of the way up the canyon.

Despite the arid climate of Death Valley, infrequent but intense convective storms can cause flash flooding. This flooding may severely damage roads and structures, and create hazards to visitor safety in the canyon locations of the monument.

Estimates of flood magnitude and frequency for Grapevine Canyon were derived from equations based on a regional analysis of floods in similar areas throughout the desert regions of southern California. Potential hazards due to flash flooding in Grapevine Canyon are defined, and a detailed flood inundation map was prepared for the facilities in the Scotty's Castle area.

Results of this study indicate that high-velocity flows of water and debris, even at shallow depths, may scour and damage Grapevine Canyon Road. When discharge exceeds 4,900 cubic feet per second, expected at a recurrence interval of between 25 and 50 years, the Scotty's Castle access road and bridge may be damaged and the parking lot partly inundated. A flood having a 100-year or greater recurrence interval probably would wash out the bridge and present a hazard to the stable and garage buildings but not to the castle buildings, whose foundations are higher than the predicted maximum flood level.
\end{abstract}




\section{INTRODUCTION}

Within Death Valley National Monument, there are many areas of scenic, geologic, ecological, and historical interest. At various times of the year these areas receive heavy visitor traffic. One of the most popular visitor attractions in the monument is Scotty's Castle, which is in Grapevine Canyon (fig. 1 and pl. 1) on the western slope of the Grapevine Mountains about 40 miles northeast of Stovepipe Wells Village.

Death Valley commonly is regarded as the driest and hottest region in the United States. Despite the arid climate of the Death Valley area, infrequent but intense storms cause localized flash flooding, which may severely damage roads, buildings, and other cultural developments in the floodway. Consequently, visitors to the monument could be endangered by such flooding.

Because of this potential risk, the U.S. Geological Survey in cooperation with the National Park Service identified and evaluated potential flood hazards in the monument. This report covers the Grapevine Canyon area, with an emphasis on the Scotty's Castle visitor area. The U.S. Geological Survey has published two previous reports on flood hazards in the monument: one for the Furnace Creek area and the other for Wildrose Canyon (Crippen, 1979; 1981).

The scope of the study included compiling precipitation and runoff data, surveying 18 cross sections along the channel of Grapevine Creek and 2 in Tie Canyon, and constructing plots of the channel-bed and Grapevine Canyon Road profiles. Estimates of flood magnitude and frequency for Grapevine Canyon were derived, and a flood-inundation map was prepared for the Scotty's Castle area.

\section{GEOGRAPHIC SETTING}

Death Valley Scotty's Castle is about one-third of the way up Grapevine Canyon near the mouth of Tie Canyon, the major tributary (fig. 1). The castle is 2.8 miles northeast of the junction of Grapevine Canyon Road and the road to Ubehebe Crater (point $A$ in fig. 1).

Grapevine Canyon Creek drains the steep western slope of the Grapevine Mountains, which form part of the eastern boundary of Death Valley. The Grapevine Mountains are underlain by intensely folded and faulted sedimentary rocks of Paleozoic age. In the central to northern part of the range, the sedimentary rocks are capped by volcanic basalts of Tertiary age (Miller, 1977).

Grapevine Canyon basin is fan shaped, trending northeast to southwest, and has a total area at point A of $47.9 \mathrm{mi}^{2}$ (fig. 1). The northeast boundary of the basin is the crest of the Grapevine Mountains. The drainage area above point I (upper Grapevine basin) is $18.0 \mathrm{mi}^{2}$. The Tie Canyon basin, which has an area of $14.5 \mathrm{mi}^{2}$, constitutes the northwestern part of Grapevine Canyon basin. Elevations in Grapevine Canyon basin range from 7,008 feet above sea level at Helmet Peak to 2,298 feet at point A (pl. 1). Elevations of the channel bed in the study reach range from 3,920.2 feet at point I to 2,333.4 feet at section 12, 0.15 mile upstream of data point A. The average channel slope is about 217 feet per mile, which is similar to the 190 foot-per-mile slope (of the lower 10.5-mile reach) of Furnace Creek Wash (Crippen, 1979, p. 9).

Much of Grapevine Canyon basin upstream from point $I$ is a plateau-like region of broad and flat coalescing alluvial fans that were formed by several tributaries. Where the stream enters the narrow constriction in the upper reaches of Grapevine Canyon near the monument boundary at point I (fig. 1), the channel steepens and becomes well defined. From point $I$ downstream to point $F$, the main channel meanders across the canyon and occupies about one-fourth of the canyon floor. Below point $F$, the stream is confined to a narrow gorge in which the road occupies the entire canyon floor. The gorge continues downstream for about 1.3 miles to point $\mathrm{E}$, where the channel widens. At this point, tributaries enter the main channel from both the north and south. These tributaries have formed small alluvial fans that extend into the main channel and reduce the main-channel slope. 
Below point E, the channel passes through a constriction and the slope again steepens. Between this point and the Scotty's Castle area at point $D$, the channel is incised near the north side of the canyon; and the road is elevated on the south side of the canyon. In the vicinity of the castle, the road is elevated above the canyon floor near the south side of the canyon; and the channel bed is confined to the middle of the canyon floor. The channel slope lessens in this reach because of an alluvial fan at the mouth of Tie Canyon.

Downstream from point $D$ to point $A$, the road is about 200 feet south (and east) of the channel; and the slopes of channel and road are similar, except that the road alternately dips down to the elevation of the channel bed and then rises over spurs that extend from the hills on the south side of the canyon.

Stationing for cross sections along the stream channel is measured upstream from point A. Eighteen cross sections were surveyed in July 1982 and January 1983 to sea level datum. The datum for the two cross sections surveyed in Tie Canyon was taken from contour maps (dated 1971; scale 1 inch equals 100 feet) of the Scotty's Castle area that were supplied by the National Park Service. Elevations and stationing of cross sections and data points are shown in table 1. Plots of the channel-bed and road profiles in Grapevine Canyon are shown in figure 1.

TABLE 1.--Channel-bed and road elevations in Grapevine Canyon

[Location of data points and cross sections shown in figure 1]

\begin{tabular}{|c|c|c|c|c|c|c|}
\hline \multirow{2}{*}{$\begin{array}{l}\text { Distance from } \\
\text { initial point } \\
\text { at mouth of } \\
\text { canyon } \\
\text { (point } \mathrm{A} \text { ), } \\
\text { in feet }\end{array}$} & \multirow{2}{*}{$\begin{array}{l}\text { Data } \\
\text { point }\end{array}$} & \multirow{2}{*}{$\begin{array}{c}\text { Drainage } \\
\text { area, in } \\
\text { square } \\
\text { miles }\end{array}$} & \multirow{2}{*}{$\begin{array}{l}\text { Cross } \\
\text { section }\end{array}$} & \multicolumn{2}{|c|}{$\begin{array}{l}\text { Elevation, in feet } \\
\text { above sea level }\end{array}$} & \multirow[b]{2}{*}{ Remarks } \\
\hline & & & & $\begin{array}{c}\text { Channel } \\
\text { bed }\end{array}$ & $\begin{array}{l}\text { Centerline } \\
\text { of road }\end{array}$ & \\
\hline 0 & A & 47.9 & -- & - & ${ }^{1} 2,298$ & Mouth of canyon. \\
\hline 792 & - & - & 12 & $2,333.4$ & $2,336.2$ & - \\
\hline 1,056 & B & 47.2 & - & - & ${ }^{1}, 410$ & - \\
\hline 3,643 & -- & -- & 11 & $2,457.8$ & $2,465.5$ & .. \\
\hline 8,078 & $\mathrm{C}$ & 46.6 & - & - & $1_{1,660}$ & Tributary from southeast. \\
\hline 9,029 & -. & -- & 10 & $2,706.2$ & $2,706.9$ & At Narrows. \\
\hline 13,886 & -- & -- & $9 \mathrm{~B}$ & $2,905.2$ & $2,923.7$ & -. \\
\hline 14,283 & $\mathrm{D}+$ & 44.6 & $9 \mathrm{~A}$ & $2,949.4$ & $2,959.5$ & Confluence of Grapevine and Tie Canyons. \\
\hline 14,663 & -. & -- & 9 & $2,975.9$ & $2,991.8$ & -- \\
\hline 14,678 & $\mathrm{D}$ & 30.1 & - & $2,979.8$ & $2,991.8$ & At Castle Gate Bridge. \\
\hline 14,713 & -- & -- & $8 \mathrm{~A}$ & $2,983.2$ & $2,991.4$ & -- \\
\hline 14,958 & - & -- & 8 & $2,991.8$ & $2,996.0$ & -. \\
\hline 15,163 & -- & .. & $7 \mathrm{~A}$ & $3,004.8$ & $3,014.1$ & -. \\
\hline 15,548 & -. & -- & 7 & $3,024.2$ & $3,038.5$ & -- \\
\hline 16,218 & .. & -- & 6 & $3,056.6$ & $3,071.9$ & -- \\
\hline 21,595 & -. & -- & 5 & $3,296.8$ & $3,298.8$ & - \\
\hline 22,282 & E & 29.1 & -- & -- & ${ }_{3,325}$ & Tributaries from north and south. \\
\hline 23,587 & -- & -- & $4 \mathrm{~A}$ & 3,349.4 & $3,350.1$ & At upstream end of gorge. \\
\hline 24,449 & - & -- & - & $1_{3,390}$ & 13,390 & Downstream end of gorge. \\
\hline 28,618 & - & -- & 4 & $3,564.2$ & $3,565.0$ & In gorge. \\
\hline 30,202 & - & -- & 3 & $3,621.9$ & $3,622.3$ & Upstream end of gorge. \\
\hline 31,046 & $\mathbf{F}$ & 26.6 & - & - & $1_{3,360}$ & Tributary from north. \\
\hline 32,789 & -- & -- & 2 & $3,710.0$ & $3,710.8$ & -. \\
\hline 34,320 & -- & -- & $1 \mathrm{~A}$ & $3,773.0$ & $3,774.4$ & -- \\
\hline 36,432 & G & 22.2 & - & -- & $1_{3,840}$ & Tributary from south. \\
\hline 37,963 & $\mathbf{H}$ & 20.2 & -- & -- & ${ }_{3,870}$ & Tributary from south. \\
\hline 39,389 & I & 18.0 & 1 & $3,920.2$ & $3,921.6$ & At eastern monument boundary. \\
\hline
\end{tabular}

\footnotetext{
${ }^{1}$ Elevation derived from topographic map and shown to nearest foot only.
} 


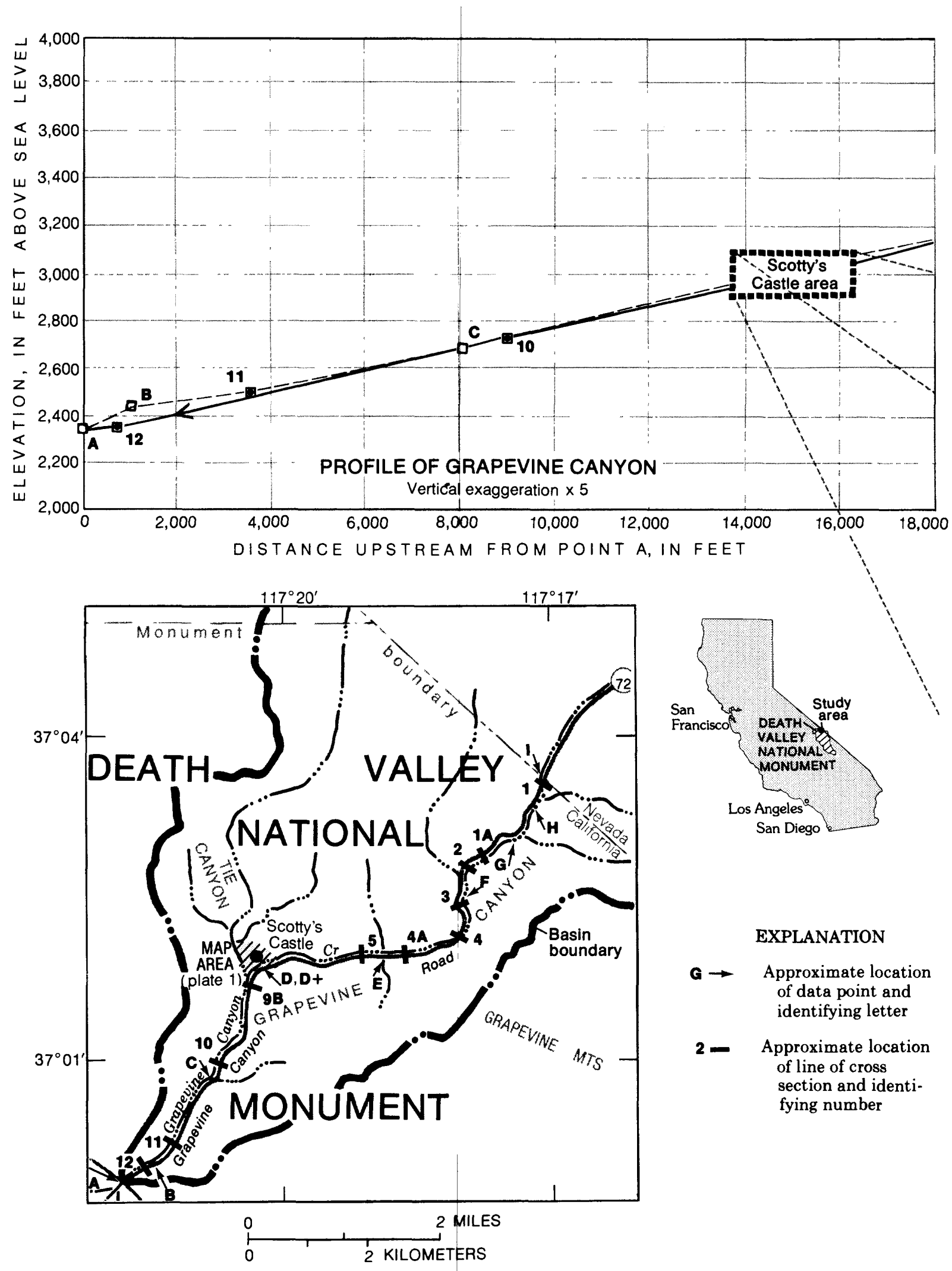

FIGURE 1.--Profile of Grapevine Canyon and map showing location of cross sections and data points. 


\section{PRECIPITATION}

As is common throughout the interior of southern California, general winter storms that cover large areas bring most of the precipitation that occurs during the months of November to March. These winter storms are likely to bring relatively light precipitation. The more rare but often intense rainfalls of summer storms, from July through September, are the cause of most damaging floodflows (Crippen, 1981, p. 5).

Rainfall generally is light and scattered throughout the Grapevine Canyon basin, but it varies with elevation. The seasonal distribution of precipitation is similar to that of Furnace Creek basin (Crippen, 1979, p. 4). Mean annual precipitation on the floor of Death Valley, on the basis of more than 50 years of data, is less than 2 inches. According to Hunt and others (1966, p. 36), mean annual precipitation increases about two-thirds of an inch for each 1,000-foot increase in elevation, up to about 5,000 feet.

A specific example of the areal and seasonal variability of precipitation and resultant runoff in this area is indicated by peak-discharge data for two streams within the monument for the 1969 water year. Storms during January and February 1969 produced many peaks of record at gaging stations in southern California. At the crest-stage gage on Spring Creek at Furnace Creek Inn (station 10251200) the annual peak occurred on February 25, 1969; however, at the gage on Big Dip Creek near Stovepipe Wells (station 10251000), just 42 miles north, the annual peak occurred on July 20, 1969 (Waananen, 1973). During the same year, National Park Service precipitation records at the Grapevine Ranger Station, 1.2 miles south of point A (fig. 1), show that the maximum daily precipitation of 0.80 inches occurred on January 21, 1969; however, the maximum peak discharge at Big Dip Creek near Stovepipe Wells, only 8.5 miles away, occurred in July. These data indicate that even during major winter storms the areal distribution of precipitation and areas subject to flooding in Death Valley vary greatly.

\section{FLOOD HYDROLOGY}

Historical flood peaks have not been measured in the Grapevine Canyon basin; therefore, estimates of floods for Grapevine Canyon were derived using equations based on a regional analysis of floods throughout the deserts of southern California. These regional equations are presented in a report by Waananen and Crippen (1977). For arid regions, the equations are derived using only data from basins less than $25 \mathrm{mi}^{2}$ in area.

The equations by Waananen and Crippen (1977), which are assumed to be valid for use in the vicinity of Grapevine Canyon, are:

$$
\begin{aligned}
Q_{25} & =410 A^{0.63}, \\
Q_{50} & =700 A^{0.68}, \text { and } \\
Q_{100} & =1,080 A^{0.71},
\end{aligned}
$$

where

$Q_{n}$ is the respective $n$-year ${ }^{1}$ peak discharge, in cubic feet per second, and

$A$ is the drainage area, in square miles.

The probability of exceedence in any one year may be estimated as the reciprocal of recurrence interval using the equation:

$$
P=\frac{1}{n}
$$

${ }^{1}$ For example, $Q_{25}$ is the 25 -year peak discharge. The value of $n$ is the recurrence interval. 
where

$P$ is the probability of exceedence in any one year and

$n$ is the recurrence interval, in years.

Crippen (1982) developed a general equation for estimated maximum floods in the desert regimes of the Basin and Range province. A modified form of that equation for use in Death Valley (Crippen, 1979) is:

$$
Q_{m e}=66,000 A^{1.029} Z^{-1.341},
$$

where

$Q_{m e}$ is the estimated maximum flood discharge, in cubic feet per second;

$A$ is the drainage area, in square miles; and

$Z$ is $A^{0.5}+5$.

Drainage areas were computed for selected locations along Grapevine Canyon Creek (fig. 1, table 1). For these drainage areas, discharges were computed for selected recurrence intervals and are given in table 2.

The most significant flood peak in recent years in the Scotty's Castle area occurred in July 1976 as a result of an intense convective storm in the Grapevine Mountains. On the basis of depth and width observations made by National Park Service personnel (oral commun., 1983), a discharge of $2,900 \mathrm{ft}^{3} / \mathrm{s}$ was estimated for the reach in the vicinity of cross section 6 (pl. 1). This flood approximates the computed 25 -year recurrence interval flood at cross section 6 of $3,500 \mathrm{ft}^{3} / \mathrm{s}$. It is interesting to note that the National Park Service reported no rain at Scotty's Castle during the July 1976 flood.

TABLE 2.--Estimated flood discharges at cross sections in Grapevine and Tie Canyons

[Locations shown in figure 1 and on plate 1 . Recurrence interval is in years, except $Q_{m e}$ is peak discharge from modified equation for estimated maximum floods in Death Valley (Crippen, 1982). Drainage areas at data points A-I that were used to calculate discharges are given in table 1]

\begin{tabular}{|c|c|c|c|c|c|}
\hline \multirow{2}{*}{$\begin{array}{l}\text { Recurrence } \\
\text { interval }\end{array}$} & \multicolumn{5}{|c|}{ Discharge, in cubic feet per second, at indicated cross sections } \\
\hline & 1 & $1 \mathrm{~A}, 2$ & $3,4,4 \mathrm{~A}$ & 5 & $6,7,7 \mathrm{~A}, 8,8 \mathrm{~A}$ \\
\hline 25 & 2,530 & 2,890 & 3,240 & 3,430 & 3,500 \\
\hline 50 & 5,000 & 5,760 & 6,520 & 6,930 & 7,090 \\
\hline 100 & 8,410 & 9,760 & 11,100 & 11,800 & 12,100 \\
\hline$Q_{m e}$ & 65,400 & 76,000 & 86,300 & 91,600 & 93,700 \\
\hline \multirow{2}{*}{$\begin{array}{l}\text { Recurrence } \\
\text { interval }\end{array}$} & \multicolumn{5}{|c|}{ Discharge, in cubic feet per second, at indicated cross sections } \\
\hline & $9 A, 9 B$ & 10 & 11 & 12 & Tie A, Tie B \\
\hline 25 & 4,490 & 4,520 & 4,610 & 4,650 & 990 \\
\hline 50 & 9,260 & 9,460 & 9,550 & 9,620 & 2,170 \\
\hline 100 & 16,000 & 16,340 & 16,500 & 16,600 & 3,900 \\
\hline$Q_{m e}$ & 122,000 & 124,000 & 125,000 & 126,000 & 28,300 \\
\hline
\end{tabular}




\section{Flood Profiles for Grapevine Canyon and Scotty's Castle Area}

Water-surface elevations (table 3) were calculated, using step-backwater and slope-conveyance procedures, on the basis of discharges for selected recurrence-interval floods and the cross-section data from the surveys done in July 1982 and January 1983 . These water-surface elevations then were used to define flood levels (fig. 2) and areas of inundation (pl. 1).

The procedures that were used assume that the water surface is level between banks and that the channel cross sections remain constant throughout the flood. The estimates of water-surface elevations contain uncertainty because of the tendency of high flows to alter the channel shape and capacity by scour and deposition as the floodwave passes down the channel.

All computed discharges were in the supercritical flow regime, except at section $8 \mathrm{~A}$ at the approach to the bridge. It is considered likely that during floodflows that approach supercritical conditions, extensive channel erosion will tend to reduce the velocity of flow and lower the water-surface elevation. During these floodflows, large quantities of debris will be carried and superelevation of the water surface will occur at the outside of channel bends.

The discharges computed for the estimated maximum flood are qualified by Crippen (1979) as flows that would in many places exceed the capacity of the channels as they now exist. Therefore, the computed water-surface elevations for these flows are considered uncertain.

The results of hydraulic analysis for extreme flows contain uncertainty because areas where channels did not previously exist may be inundated as a result of scour, altered channel alignment, or landslides that block the channel. Furthermore, backwater at constrictions may cause water to overflow the banks. Some of the overflow may return to the original channel at downstream points, or new channels may be formed. Even though magnitudes of estimated maximum flows are given, and inferred areas of inundation are indicated (pl. 1), it is not possible to define accurately the potential hazard areas.

Computed water-surface elevations for the 25-year, 100-year, and estimated maximum $\left(Q_{m e}\right)$ floods at cross sections on Grapevine Canyon and Tie Canyon are shown in figure 2.

The 25-year recurrence-interval flood is of particular interest because of observations made in the Scotty's Castle area during the July 1976 flood. Overflow during this flood cut a narrow, deep channel through the middle of the parking area (National Park Service personnel, oral commun., 1983), rather than maintaining a stable bed configuration at cross sections 7 and $7 \mathrm{a}(\mathrm{pl} .1$ ). Because of this evidence of channel instability, the calculated elevations can be used only as a guide when evaluating potential flood hazards. 
TABLE 3.--Estimated flood levels at cross sections in Grapevine and Tie Canyons

[Flood-level elevations in feet above sea level. Locations shown in figure 1 and on plate 1. Recurrence interval is in years, except $Q_{m e}$ is peak discharge from modified equation for estimated maximum floods in Death Valley (Crippen, 1982)]

\begin{tabular}{|c|c|c|c|c|c|c|c|c|c|}
\hline \multirow{2}{*}{$\begin{array}{l}\text { Recurrence } \\
\text { interval }\end{array}$} & \multicolumn{9}{|c|}{ Flood-level elevation at indicated cross sections } \\
\hline & 12 & 11 & 10 & 9B & $9 A$ & $8 \mathrm{~A}$ & 8 & $7 \mathrm{~A}$ & 7 \\
\hline 25 & $2,337.5$ & $2,461.1$ & $2,709.8$ & $2,908.3$ & $2,955.7$ & $2,987.3$ & $2,994.0$ & $3,007.3$ & $3,028.0$ \\
\hline 50 & $2,338.5$ & $2,462.3$ & $2,711.3$ & $2,909.0$ & $2,956.8$ & $2,994.7$ & $2,995.0$ & $3,008.1$ & $3,029.0$ \\
\hline 100 & $2,339.5$ & $2,463.9$ & $2,712.8$ & $2,909.8$ & $2,957.8$ & $\begin{array}{c}2,995.8 \\
\left({ }^{1} 2,988.2\right)\end{array}$ & $2,996.0$ & $3,009.0$ & $3,030.1$ \\
\hline$Q_{m e}$ & $2,346.5$ & $2,471.5$ & $2,725.1$ & $2,915.5$ & $2,963.8$ & $\begin{array}{c}3,001.0 \\
\left({ }^{1} 2,994.9\right)\end{array}$ & $3,002.5$ & $3,015.0$ & $3,037.0$ \\
\hline
\end{tabular}

\begin{tabular}{|c|c|c|c|c|c|c|c|c|c|c|}
\hline \multirow{2}{*}{$\begin{array}{c}\text { Recurrence } \\
\text { interval }\end{array}$} & \multicolumn{10}{|c|}{ Flood-level elevation at indicated cross sections } \\
\hline & 6 & 5 & $4 \mathrm{~A}$ & 4 & 3 & 2 & $1 \mathrm{~A}$ & 1 & Tie B & Tie A \\
\hline 25 & $3,060.2$ & $3,300.3$ & $3,352.7$ & $3,568.3$ & $3,624.7$ & $3,712.5$ & $3,776.3$ & $3,922.5$ & $3,007.5$ & $3,046.3$ \\
\hline 50 & $3,060.9$ & $3,301.3$ & $3,354.0$ & $3,569.8$ & $3,625.8$ & $3,713.4$ & $3,777.3$ & $3,922.9$ & $3,008.2$ & $3,047.0$ \\
\hline 100 & $3,061.6$ & $3,302.5$ & $3,355.5$ & $3,571.5$ & $3,627.1$ & $3,714.3$ & $3,778.3$ & $3,923.3$ & $3,008.8$ & $3,047.6$ \\
\hline$Q_{m e}$ & $3,067.9$ & $3,311.3$ & $3,363.5$ & $3,588.0$ & $3,637.5$ & $3,722.3$ & $3,785.3$ & $3,927.1$ & $3,012.1$ & $3,051.7$ \\
\hline
\end{tabular}

${ }^{1}$ Calculated assuming bridge and embankments washed out. 



EXPLANATION

WATER-SURFACE ELEVATIONS FOR FLOODS

OF SELECTED RECURRENCE INTERVALS-

Vertical exaggeration $\mathrm{x} 14$

$\begin{array}{r}Q_{25} \\ Q_{100} \\ \hline \text { Qme }\end{array}$

25 year

100 year

Estimated maximum

Note: 100 -year and estimated maximum flood elevations were calculated on the basis of the assumption that bridge abutments ( $B$ on plate 1 ) would wash out at a flow greater than that of a 50-year flood and less than that of a 100-year flood

(2) CROSS-SECTION NUMBER (See figure 1 for location of cross sections)

FIGURE 2.--Cross sections of Grapevine and Tie Canyons showing 25-year, 100-year, and estimated maximum flood levels. (Part 1 of 4.) 

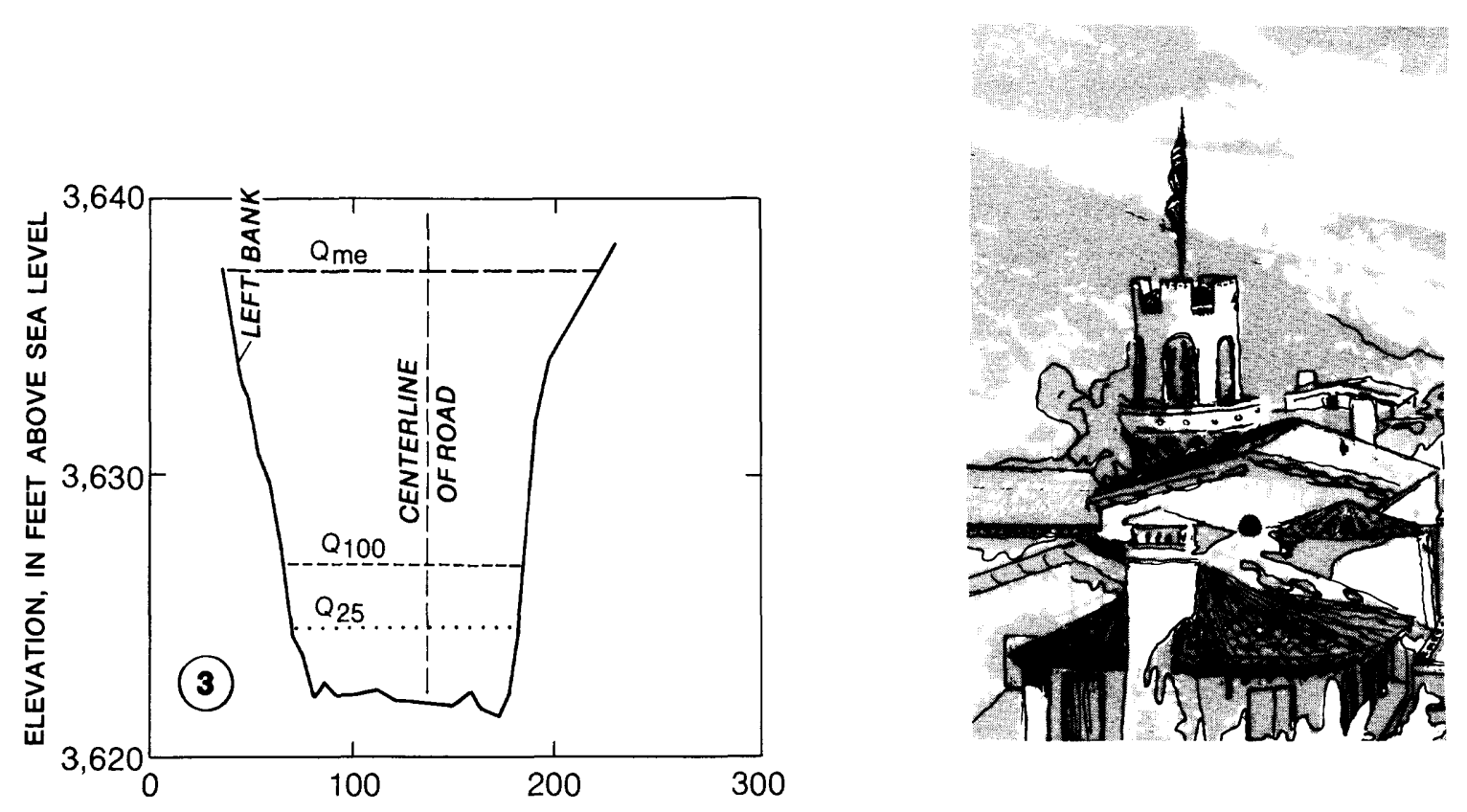

DISTANCE, IN FEET FROM ARBITRARY INITIAL POINT
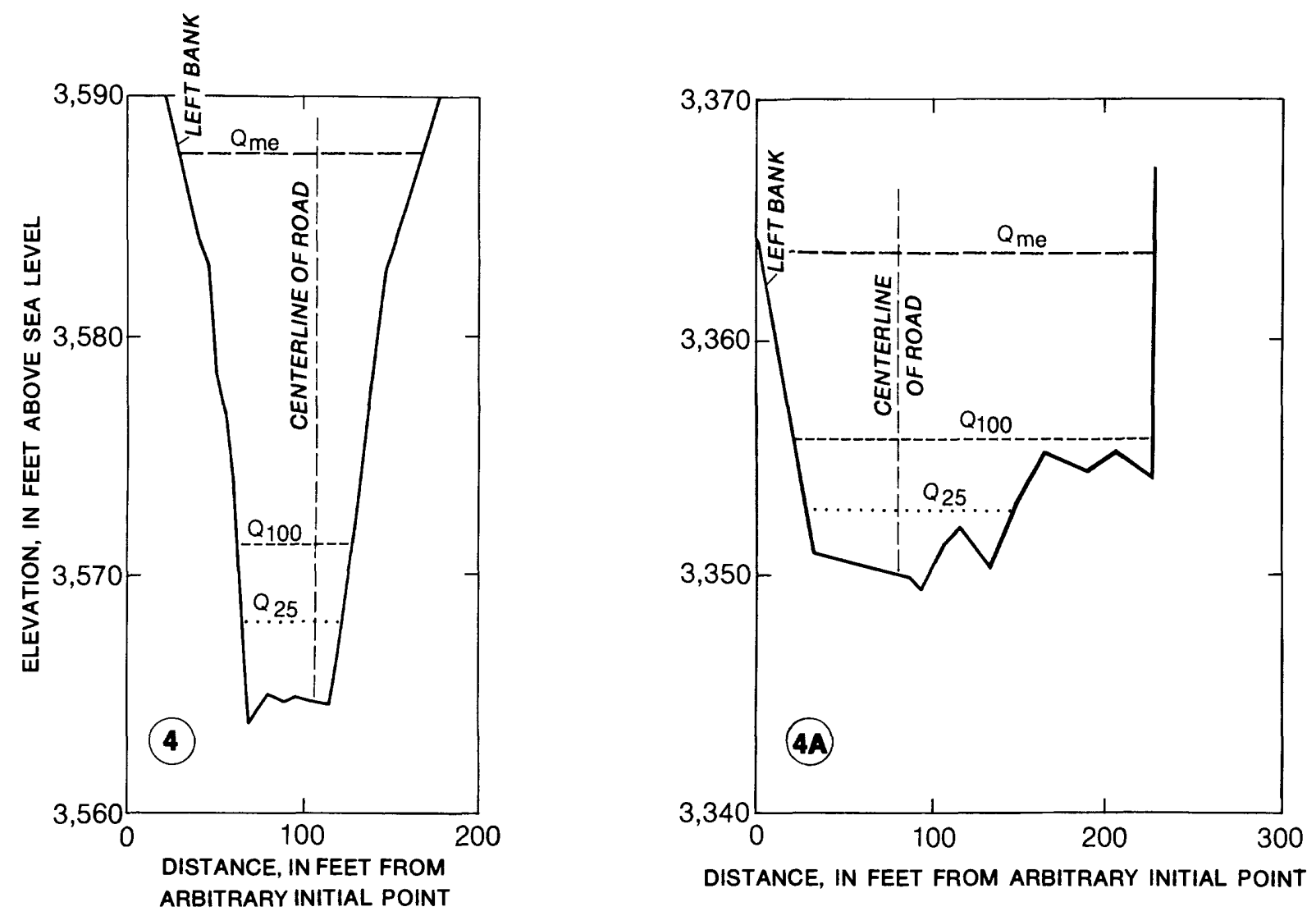

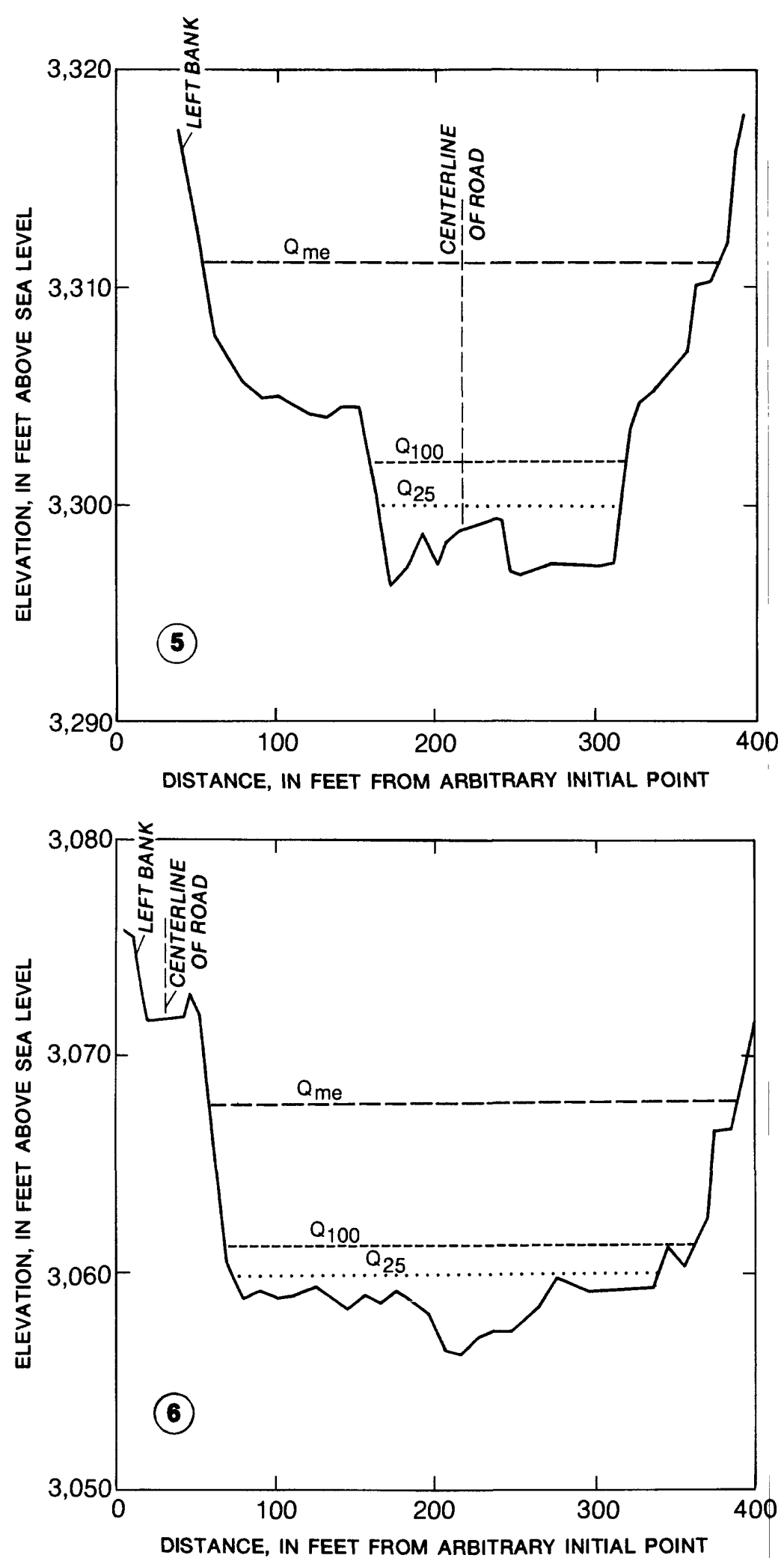

FIGURE 2.-- Continued. ( Part 2 of 4. )

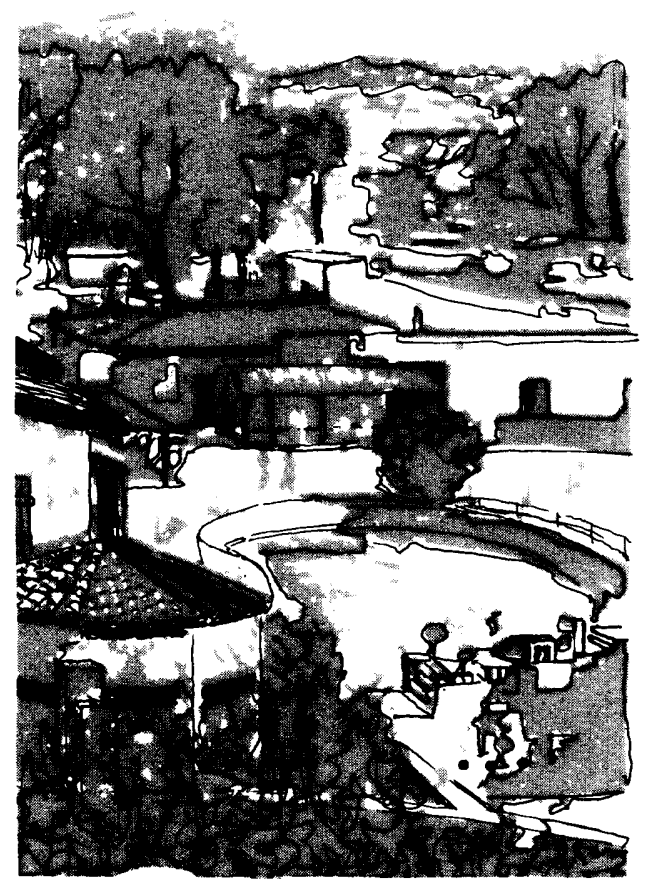

\section{EXPLANATION}

WATER-SURFACE ELEVATIONS FOR FLOODS OF SELECTED RECURRENCE INTERVALS -$Q_{25}$ Vertical exaggeration $\times 14$

........ 25 year $Q_{100} \quad 100$ year

Q me - Estimated maximum

Note: 100 -year and estimated maximum flood elevations were calculated on the basis of the assumption that bridge abutments ( $B$ on plate 1 ) would wash out at a flow greater than that of a 50 year flood and less than that of a 100 year flood

6) CROSS-SECTION NUMBER (See figure or plate 1 for location of cross sections) 

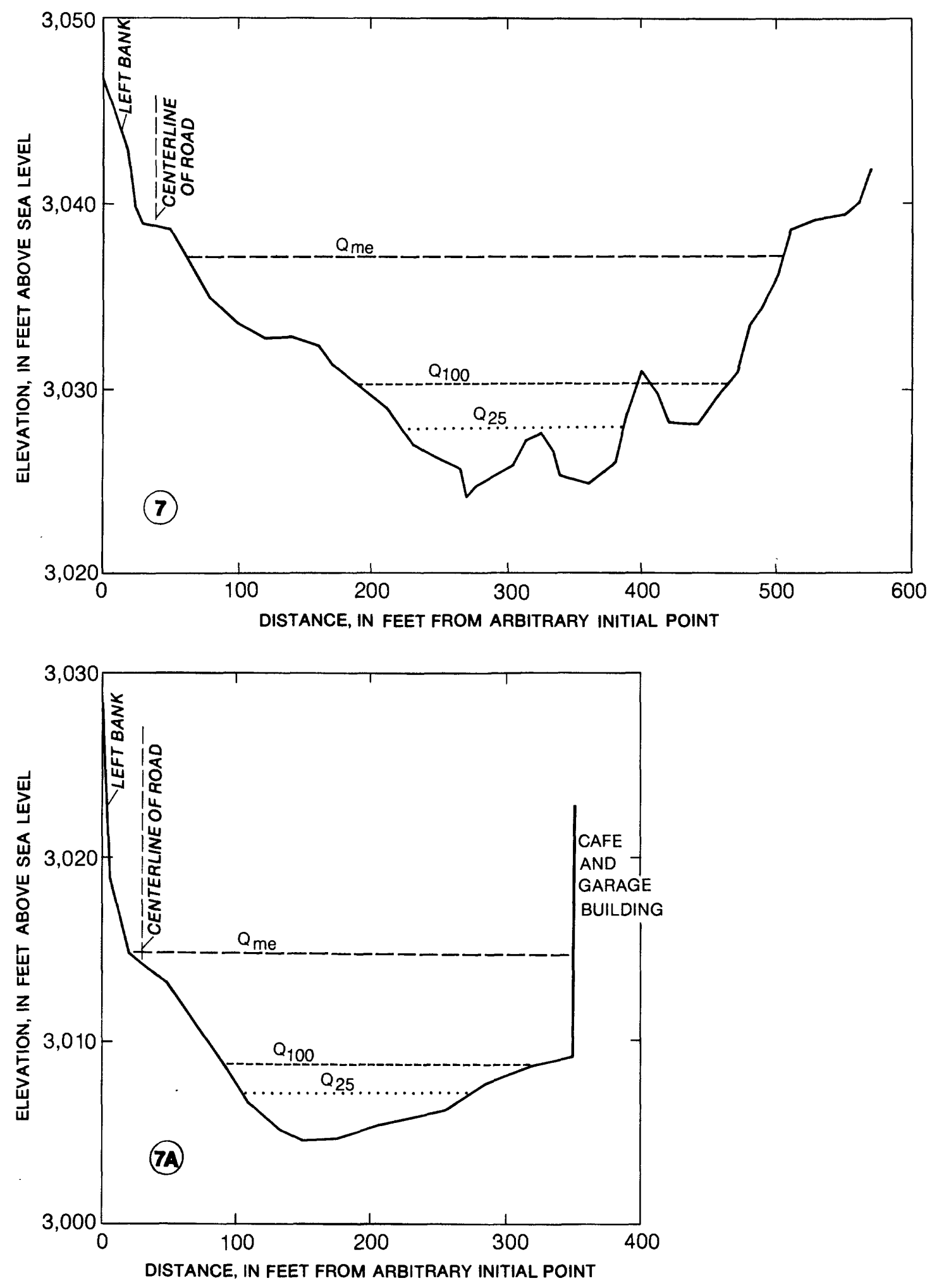

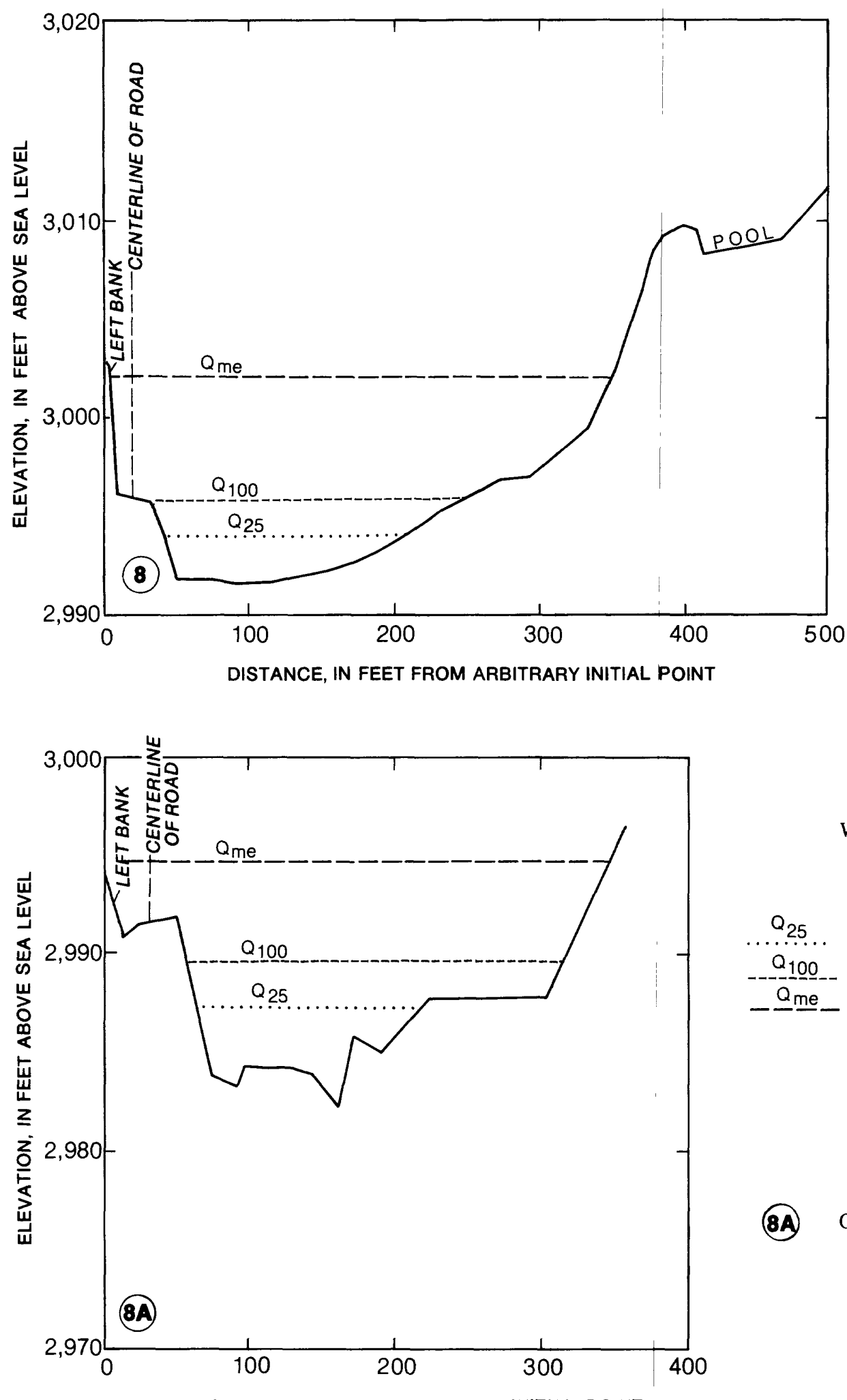

\section{EXPLANATION}

WATER-SURFACE ELEVATIONS FOR FLOODS OF SELECTED RECURRENCE INTERVALS -Vertical exaggeration $\mathrm{x} 14$

$\mathrm{Q}_{25} \ldots \quad 25$ year

Q 100 year

- $\underline{\text { me }}$ _ Estimated maximum

Note: 100 -year and estimated maximum flood elevations were calculated on the basis of the assumption that bridge abutments ( $B$ on plate 1 ) would wash out at a flow greater than that of a 50 year flood and less than that of a 100 year flood

(8A) CROSS-SECTION NUMBER (See figure 1 or plate 1 for location of cross sections)

FIGURE 2.--Continued. (Part 3 of 4.) 

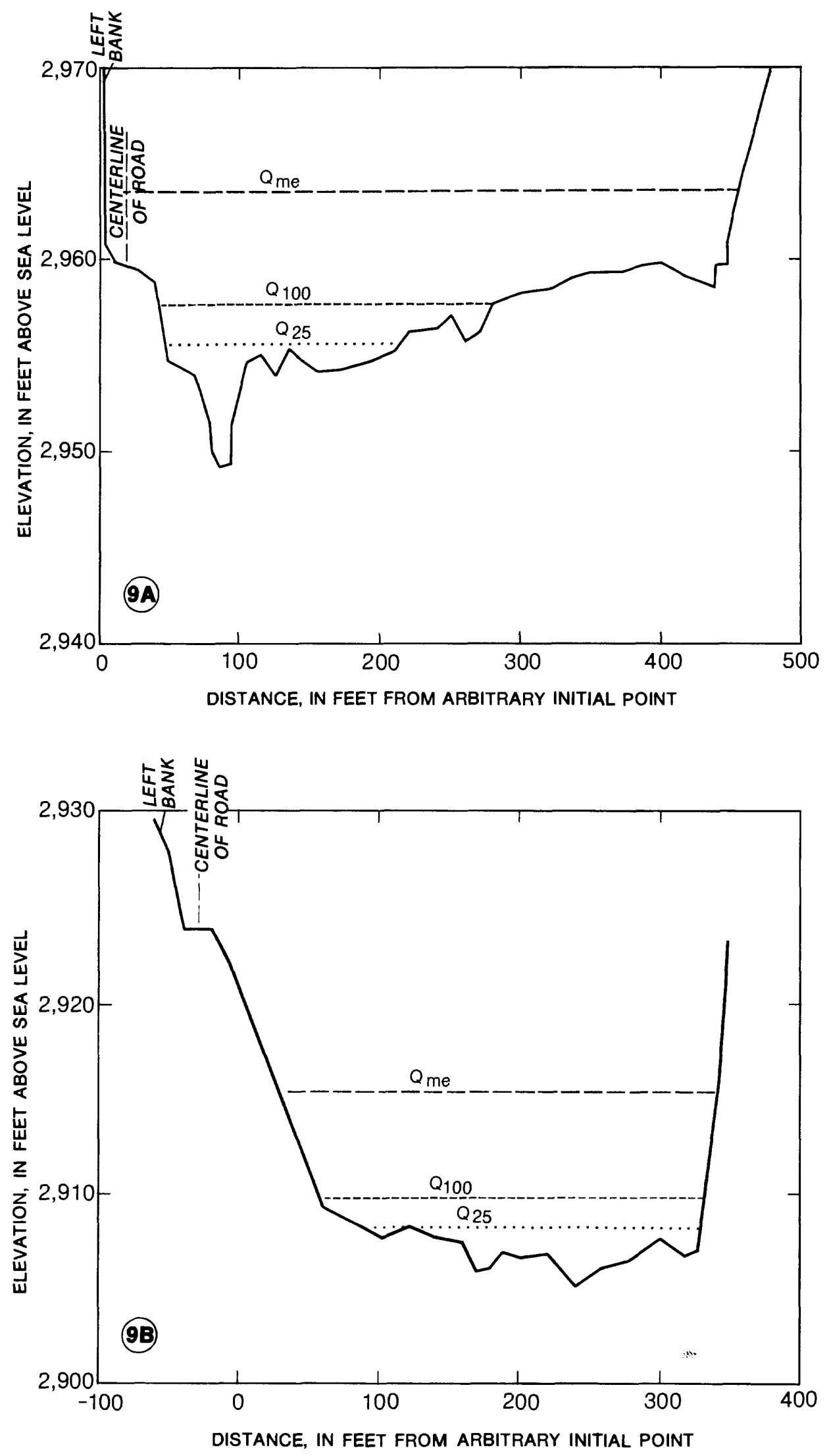

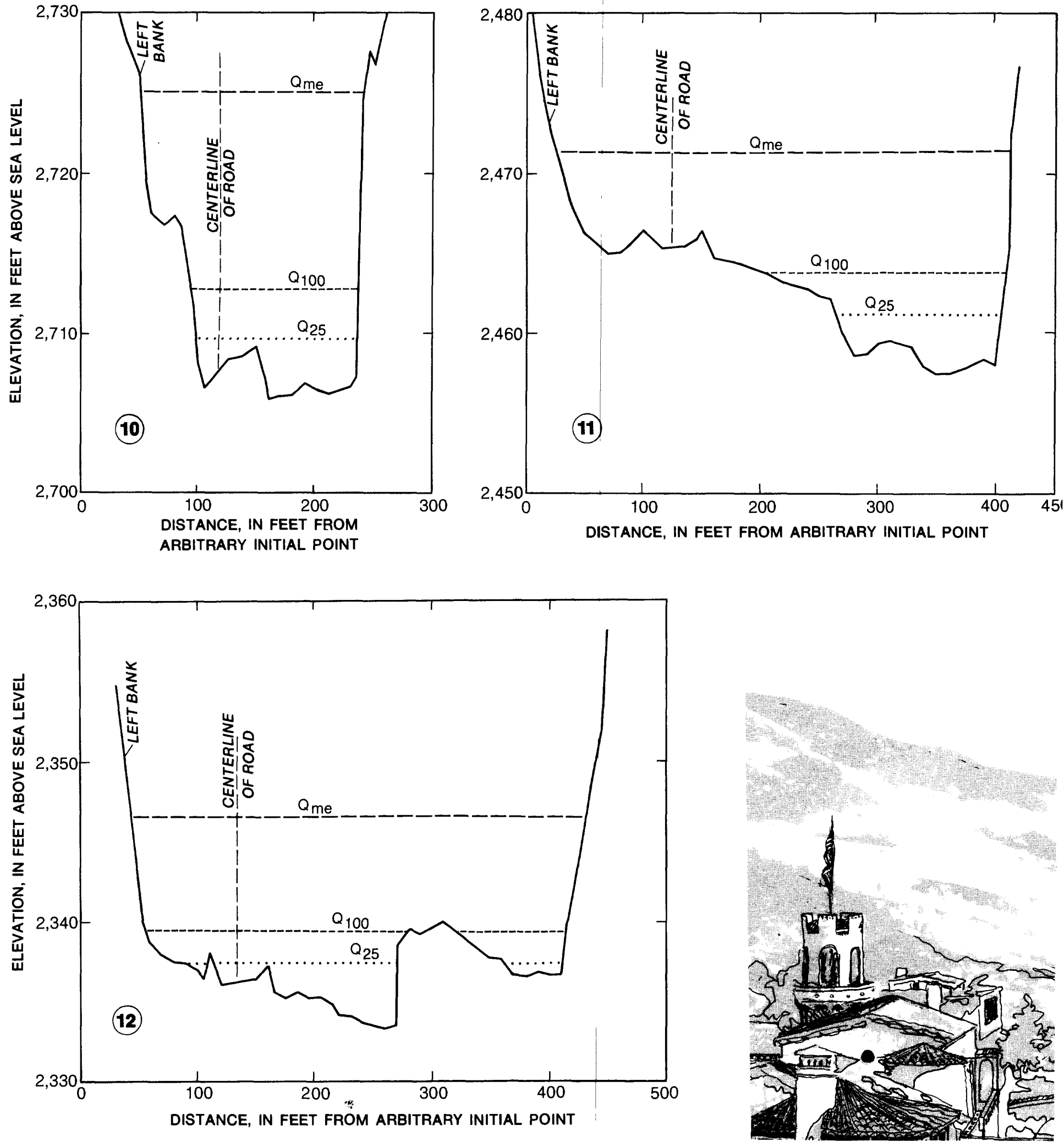

FIGURE 2.--Continued. (Part 4 of 4.) 


\section{EXPLANATION}

WATER-SURFACE ELEVATIONS FOR FLOODS OF SELECTED RECURRENCE INTERVALS -Vertical exaggeration $\times 14$

$Q_{25} \ldots$ 25 year

$Q_{10}-100$ year
$-Q_{\text {me }}$ Estimated maximum

Note: 100 -year and estimated maximum flood elevations were calculated on the basis of the assumption that bridge abutments (B on plate 1) would wash out at a flow greater than that of a 50 year flood and less than that of a 100 year flood

(11) CROSS-SECTION NUMBER (See figure 1 or plate 1 for location of cross sections)
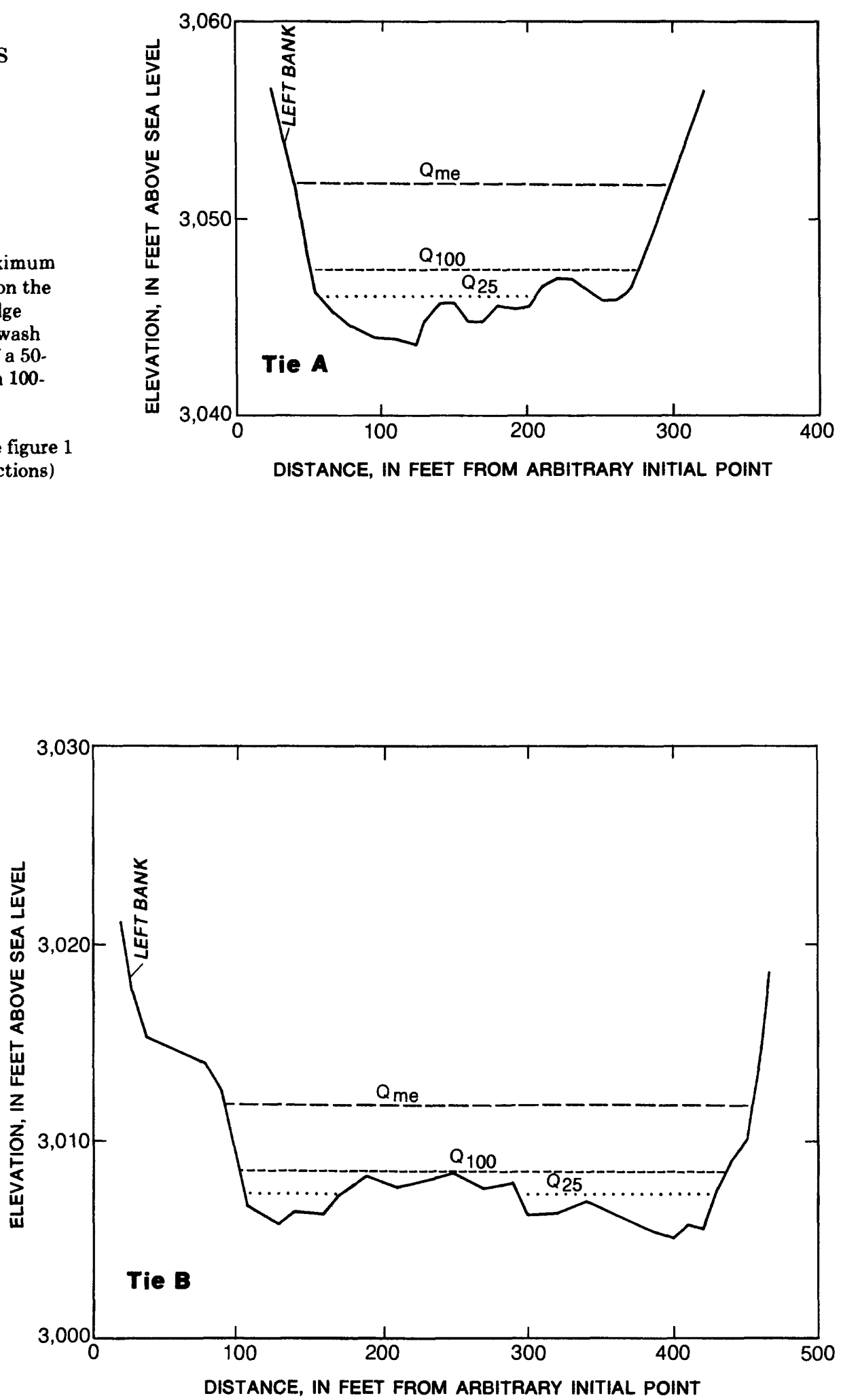


\section{ASSESSMENT OF POTENTIAL HAZARDS FROM FLOODFLOWS}

In addition to the direct hazards posed by floodflows in the main channel and overbank areas of Grapevine Canyon Creek (as shown by the areas of inundation on plate 1 and the water-surface elevations in figure 2), there is a potential hazard from sheetflow of water and debris from the steep canyon walls caused by localized intense precipitation. There also is the direct hazard of floodflows, channel scour, and debris deposited at the mouths of tributary channels near the Grapevine Canyon Road (fig. 1). These tributaries intersect the main channel at a nearly perpendicular angle, and could cause floodflow and debris to cross the road at many locations.

\section{Hazards in Grapevine Canyon}

Grapevine Canyon Road should be considered the main floodflow and debris-flow hazard in the area. All computed flood levels (see fig. 2) are above the existing road elevation at cross sections 1-5, 10, and 12; in addition, the $Q_{m e}$ level is above the road at sections $7 \mathrm{~A}, 8,9 \mathrm{~A}$, and 11 . In the gorge area, the road occupies the entire canyon floor between sections 3 and 4A (fig. 1). Even at shallow depths, high-velocity flows of water and debris may scour and damage the roadway.

The indicated hazard areas probably do not reflect the full extent of flood danger because of the steepness of the channel in Grapevine Canyon; the abundance of poorly consolidated, erodible bed material; and the likelihood of landslides and debris from the canyon walls. Floodflow is likely to occur as a series of waves of water and debris that may inundate all parts of the flood plain.

\section{Hazards in Scotty's Castle Area}

A flood-inundation map (pl. 1) was prepared for the Scotty's Castle area using procedures for computing flows through bridge openings for the 25- and 50-year recurrence interval floods. The 25- and 50-year flood boundaries were drawn with the Castle Gate Bridge and embankments assumed to be intact.

The bridge may be overtopped when discharges exceed 4,900 $\mathrm{ft}^{3} / \mathrm{s}$, expected at a recurrence interval of between 25 and 50 years. If a flood of this magnitude occurs, the access road or the bridge structure (near cross section $8 \mathrm{~A}$ ) may be damaged, preventing access to and from the castle complex. In addition, the parking lot for the complex (at cross section 7A) may be partly inundated and vehicles in the parking lot could be damaged. Scour of the channel bed and parking lot were observed during the flood of July 1976, a flood that was only slightly smaller than a 25 -year flood.

The base map for the flood-inundation map (pl. 1) was prepared from (National Park Service) aerial photographs taken in 1972 . The contour lines shown on the base map are approximate ( \pm 2 feet) near the mouth of Tie Canyon. The approximate areas of inundation and flood boundaries are inferred from the cross sections surveyed for this study and from contours on the base map. Plate 1 represents a more accurate description of flood elevations and their cross-sectional boundaries than could be derived using only the contours on the map. The elevations of the permanent structures shown on the base map were verified during the field survey for this study.

The flood-inundation boundaries for the 100 -year and $Q_{m e}$ floods were drawn using elevations computed with the bridge and earthen embankments assumed to be intact. The bridge and embankments likely would be washed out during a 100 -year or $Q_{m e}$ flood. Water-surface elevations for Section $8 \mathrm{~A}$ that were computed assuming that the bridge and embankments were washed out also are given in table 3 , but boundaries based on 
those computations are not shown on plate 1. The stable and garage buildings (near cross sections 7 and 7A) are shown between the 100-year and $Q_{m e}$ boundaries and are in an area of potential flood hazard. The Castle buildings (D-E, pl. 1) are shown to be outside the area of potential flood hazard as the foundation is higher than the predicted maximum flood level.

The Grapevine Ranger Station, which is outside the study area and is about 1.2 miles south of the canyon mouth (fig. 1), appears to be out of any direct hazard from floodflows originating from Grapevine Canyon. However, there is a potential flood hazard at the ranger station due to sheet wash from the hills and flash flooding from the small canyons in the hills to the east.

\section{SUMMARY}

Grapevine Canyon is on the western slope of the Grapevine Mountains in the northern part of Death Valley National Monument. Grapevine Canyon Road covers the entire width of the canyon floor in places and is a frequently traveled route to Scotty's Castle in the canyon.

The region is arid; however, it is subject to flash flooding because of infrequent but intense convective storms. When these storms occur, normally in the summer, the resulting floods may create a hazard to visitor safety and property.

Historical data on rainfall and floodflow in Grapevine Canyon are sparse. Data from studies done in similar areas in the desert mountains of southern California provide the basis for estimating discharges and the corresponding frequency of floods in the study area. Potential floodflow hazards are defined for Grapevine Canyon, and a detailed hazards evaluation is given for the Scotty's Castle area.

Results of this study indicate that high-velocity flows of water and debris, even at shallow depths, may scour and damage Grapevine Canyon Road. When discharge exceeds 4,900 cubic feet per second, expected at a recurrence interval of between 25 and 50 years, the Scotty's Castle access road and bridge may be damaged and the parking lot partly inundated. A flood having a 100 -year or greater recurrence interval probably would wash out the bridge and would present a hazard to the stable and garage buildings but not to the castle buildings, whose foundations are higher than the predicted maximum flood level.

\section{REFERENCES CITED}

Crippen, J.R., 1979, Potential hazards from floodflows and debris movement in the Furnace Creek area, Death Valley National Monument, California-Nevada: U.S. Geological Survey Open-File Report 79-991, 40 p.

-----1981, Potential hazards from floodflows in Wildrose Canyon, Death Valley National Monument, California-Nevada: U.S. Geological Survey Open-File Report 81-407, 23 p.

-.---1982, Envelope curves for extreme flood events: Journal of the Hydraulics Division, Proceedings of the American Society of Civil Engineers, v. 108, no. HY10, p. 1208-1212.

Hunt, C.B., Robinson, T.W., Bowles, W.A., and Washburn, A.L., 1966, Hydrologic basin, Death Valley, California: U.S. Geological Survey Professional Paper 494-B, 138 p.

Miller, G.A., 1977, Appraisal of the water resources of Death Valley, California-Nevada: U.S. Geological Survey Open-File Report 77-728, 68 p.

Waananen, A.O., 1973, Floods from small drainage areas in California: A compilation of peak data October 1958 to September 1973: U.S. Geological Survey Open-File Report, 256 p.

Waananen, A.O., and Crippen, J.R., 1977, Magnitude and frequency of floods in California: U.S. Geological Survey Water-Resources Investigations Report 77-21, 96 p. 